\title{
A RETAINING WALL RECONSTRUCTION IN KUTNÁ HORA
}

\author{
JiŘí Svoboda*, Dana HadaČová \\ Pragoprojekt, a.s. (Plc.), K Ryšánce 1668/16, 14754 Prague, Czech Republic \\ * corresponding author: jiri.svoboda@pragoprojekt.cz
}

ABSTRACT. This paper addresses the reconstruction of a historical stone retaining wall at the busy Kremnická - Táborská road in the town of Kutná Hora. The structure was in very poor condition. There was the danger of an accident involving a wall slide, or even a total collapse of the road structure. The construction site in question is located near the St. Barbara's Church, in the area of the formerly important but now historical mine Osel. With respect to the possibility of undermining, various geodetic surveys and observations of the surrounding area and rock mass were performed.

KEYwords: Retaining wall, undermined area, St. Barbara's church, Kutná Hora.

\section{INTRODUCTION}

On the basis of expert static assessment and juridical assessment of the retaining wall in Kremnická and Táborská streets a preliminary permit was issued in 2015 by the special building authority for the reconstruction works on the road no. III/3377 pertaining to the condition of the current retaining wall and the adjacent part of the road.

The wall was in serious disrepair and it was necessary for it to be fixed immediately, possibly because of the hazard of accident such as a wall slide, or even a total collapse of the road embankment.

In the first stage of construction the necessary securing works were carried out in order to avert an emergency or to eliminate its possible effects and thus preventing any danger to health or life regarding the public. The aim of the following second stage of the rehabilitation works was to finish the whole wall and road structure and ensure long-term durability, safety and functionality.

The construction site is near St. Barbara's church in the location of the important historical mine Osel. With regard to the possibility of undermining, various geodetic surveys and observations of the surrounding area and rock mass were performed. A detailed research of historical mining materials was also done with the cooperation of local citizens.

On the basis of output evaluations a definitive technical solution was adopted, mainly in areas of cave-ins, large underground space rehabilitation and roadbed remediation.

\section{Sources AND GEOLOGY}

The sources and inputs for design work were:

- design documentation for building permit by TOP CON SERVIS, s.r.o. (Ltd.), 03/2015,

- engineering-geological survey by FORVIA CZ s.r. o. (Ltd.), 03/2015,
- static assessment of the retaining wall condition by Libor Pokorný (authorized engineer for bridges and engineering structures), 05/2015,

- construction site inspection done by the designer on $01 / 07 / 2015$, which declared that the condition of the wall endangered traffic and therefore safety measures had to be taken immediately - and the very same day they actually were.

On the basis of the above mentioned sources it was concluded that the major part of the retaining wall was in serious disrepair and the work for its securing and subsequent reconstruction were to start immediately.

From the geomorphological point of view the location is part of the Kutná Hora Plateau, which is formed by crystalline rock. The plateau surface is subject to intrusion by the steeply carved valleys of local watercourses. Watercourse erosion has had a predominant impact on the formation of local steep rocky banks with bare sandstone strata benches.

Because of gravity impact and erosion processes, horizontally deposited sandstones split off along the predisposed discontinuity planes and slid into the valley in the form of blocks and benches of various sizes.

The phenomenon of open crack occurrence and the detached blocks slight inclination to the valley and the watercourse is important for stability assessment on the edge of the valley slope. This gives a very uneven shape to the rock base in the wall foundation joint.

The formerly important silver mine Osel is located in the area concerned as is the Osel vein range. In the Middle Ages the mining works were done under the sandstone layers in a zone of clay rocks or geological faults. The foundations of these workings were inadequately carried out, and that is why after the drifts were exhausted and dismantled, the clay rock gradually reduced to mush causing the present cave-ins.

We faced this reality several times during the execution of drilling work when the drilling rig slumped. 
Anchors bond lengths were also located in the mushy surrounding because of the ancient mining. That led to a considerable overconsumption of the injecting material during the anchor bond lengths execution. For illustration, the underground scheme is shown in Figure 1. The view of the original and new wall near St. Barbara's dome is captured in Figure 2 The detail of the wall is depicted in Figure 3.

\section{Essential Requirements For THE NEW DESIGN}

In designing the retaining wall reconstruction, the following requirements had to be taken into account:

- Two-way traffic in at least one lane had to be maintained in Kremnická Street during the excavations.

- Proper drainage of the retaining wall back. Underground water was not expected, but there was a risk of rain water accumulation (including water from the road surface), because of leaking at the wall back, which might cause degradation of the bedrock.

- The underground services and the surrounding buildings including the retaining walls on the opposite side of the street should not be endangered by the excavations.

- The aesthetic design had to be made according to the requirements of the National Heritage Institute.

\section{Conception of the new Design}

After meetings on conceptualisation with the ordering party (Central Bohemia Road Agency - KSUS and Kutná Hora municipality) a basic variant of the retaining wall design was set up. A monolithic reinforced concrete cantilever wall with stone lining was designed to be built in a temporarily supported excavation [1].

The temporary excavation was supported by anchored piling in such a way that any interference with the existing underground services was excluded. The continuous raised guiding wall for embedding micropiles prevented car slide to the excavation, and therefore ensured some traffic safety in Kremnická Street and also kept rainwater out of the excavation.

The reinforced concrete cantilever wall itself has a variable height circa $1.5-5.0 \mathrm{~m}$. Its total length is circa $315.0 \mathrm{~m}$. It is founded on an underlay concrete slab $0.15 \mathrm{~m}$ thick. The breadth of the footing is within 1.9 $2.5 \mathrm{~m}$ and the height $0.45-0.65 \mathrm{~m}$. The wall was mainly built in 5-6 m long sections. In some sections, where the geology was unfavourable or where there were additional static reasons, the footing was founded on steel micropiles. The wall back drainage is provided by passages embedded to the stem and the longitudinal drainage system behind the wall.

A small stone wall $0.4 \mathrm{~m}$ thick and $0.9 \mathrm{~m}$ high was built over the upper level of the retaining wall. With respect to the location (barrier curb, design velocity) there was no need to give this stone wall some dimensions as a safety barrier for traffic. The face of the new retaining wall is also walled in with stone. This lining is in the upper part gradually merged with the stone wall structure and capped with a flat stone roof $0.55 \mathrm{~m}$ wide. The aboveground stone part and the stone lining are integral parts of the retaining wall static system.

Local and overall stability of the retaining wall structure was assessed in its particular characteristic sections.

\section{Geotechnical Monitoring and MONITORING BOARD}

Geotechnical monitoring (GTM) was carried out for the contract owner directly. GTM is mandatory for structures where serious negative impacts are possible for the public or either built or neighbouring objects. The placing of some measuring points including the survey of them was undertaken in advance of the actual construction work. The rules for implementation of GTM and Monitoring Board leadership were given in the tender bid documentation.

Detailed passport of all affected buildings and underground services was made. For the second stage a new contractor was chosen. That meant, a re-passport of all objects had to be made in the zone of influence and at the same time all the observations and monitoring within the GTM had to be evaluated. The second re-passport was made at the end of construction, resulting in only two objects being damaged in the context of the construction.

A geodetic survey on objects and walls, inclinometrical observation of the rock mass, crack monitoring on objects and also regular visual control of influenced objects and underground services were all done in the field. The outputs were regularly evaluated and construction procedure was continuously modified according to the Monitoring Board and its expert conclusions. Simultaneously, the geological condition found on site was monitored with expert specialist geotechnical supervision. On the basis of output evaluations the definitive technical design was modified, mainly in the area of cave-ins and large underground space rehabilitation. Subsequently static calculations had to be resolved with impacts on design detail.

Two major cave-ins happened on the site during the construction. Right under the carriageway a free underground space of circa $65 \mathrm{~m}^{3}$ was rehabilitated. Some other surveying drills were made to find other free spaces especially under the carriageway. All these caves were filled with cement-ash mixture followed by a low-pressure cement injection.

Completion of the rehabilitation of surrounding buildings, started in advance, was also finished within the monitoring. 


\subsection{0}

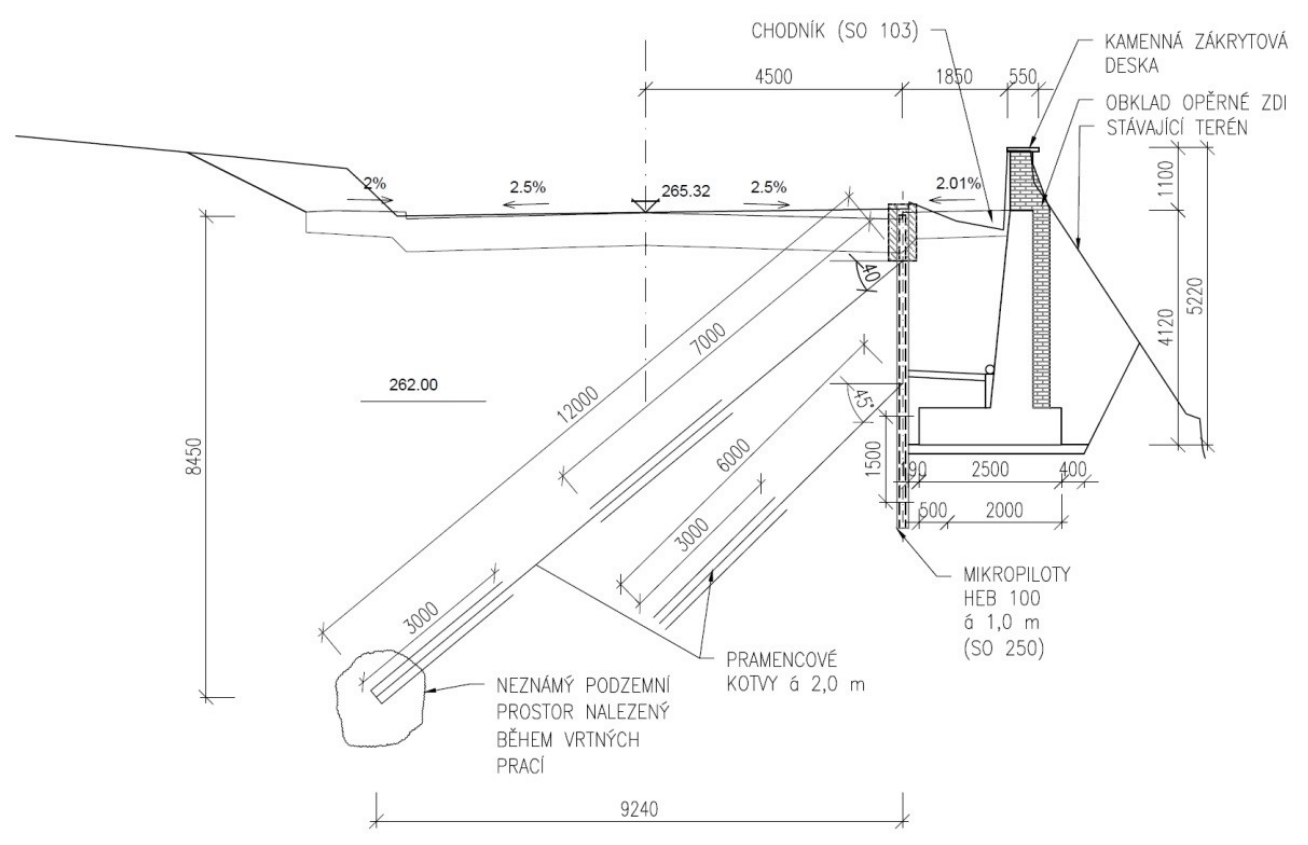

FigURE 1. Underground space scheme.

\section{On the History OF Mining in Kutná Hora}

On the basis of knowledge gathered from local citizens during re-passport and research of archival materials, especially the monograph "Kutnohorské dolování" by J. Bílek 2, it could be ascertained that the site is in the area of the important ancient mine Osel (named by a burgomaster called Asinus) in the Osel vein range. At least 50 bigger mines are estimated to have been operated in the town area from the $13^{\text {th }}$ to the $16^{\text {th }}$ century. The majority faded out during the Hussite wars.

The Osel mine manifested the wealth and heroic status of the miners in the medieval town of Kutná Hora. This mine became a status symbol of the miner and therefore a focus for mining authority. Not just the beautiful and impressive churches of St. Barbara and St. Jacob (in Kutná Hora) were built from the mining profits, but also contributions had to be made to St. Vitus Cathedral in Prague.

Mining in the Osel range expanded in the $13^{\text {th }}$ to $15^{\text {th }}$ centuries and it penetrated to the depth of almost $500 \mathrm{~m}$. In the year 1541 an underground water outflow to Osel took the life of eight miners and signalled the end of mining in 1545 .

The main shaft location has not been found until now. It is estimated to be located near the Jesuit College. The other shafts were located close to each other nearby the limestone quarry behind St. Barbara's (Mladé and Staré Rousy). The waste bank is documented in the area of Žižkov and near Všech Svatých. The deepest point of this complex was located under the Zelená Hora Street loop above the Bylanka valley.
The oldest shafts in the area concerned were opened probably before the end of the $13^{\text {th }}$ century, when the upper parts of the ore veins were mined. These were settled within small horizontal distances of 20 to $50 \mathrm{~m}$ with cross-sectional dimensions of $1.2 \times 1.5 \mathrm{~m}$, or $1.5 \times 2.0 \mathrm{~m}$. In loess and marl the shafts were timbered. The mines were drained by drainage galleries driven from the Vrchlice valley. These galleries hooked up to the shafts at a level of 30 to $50 \mathrm{~m}$ under the surface.

Shaft backfills were built almost entirely from the slag heaps. Over centuries they were affected by underground water circulation. Naturally, that would be the reason for the gradual relaxation and also often for the cave-ins. Additionally, in the shafts the clay rock gradually reduced to mush, again causing cave-ins. The risk of cave-ins in these ancient shafts and galleries is nowadays small, although it cannot be completely excluded. Therefore, any possibility must be taken into account for obvious safety reasons.

The whole Osel range consists of five rich ore veins stretching along the left side of the Vrchlice river from Holy Trinity Church to the western part of the town. The very old mining workings stretch from Bylany over so-called Cech and Vyšata quarry to the west of St. Barbara's dome. Indeed that is why the relics of mining were expected to be found on the construction site and that was proved by object movements in both Táborská and Kremnická Streets. These movements were not caused by the security actions for construction but by the presence of these very old and defunct mine workings. 

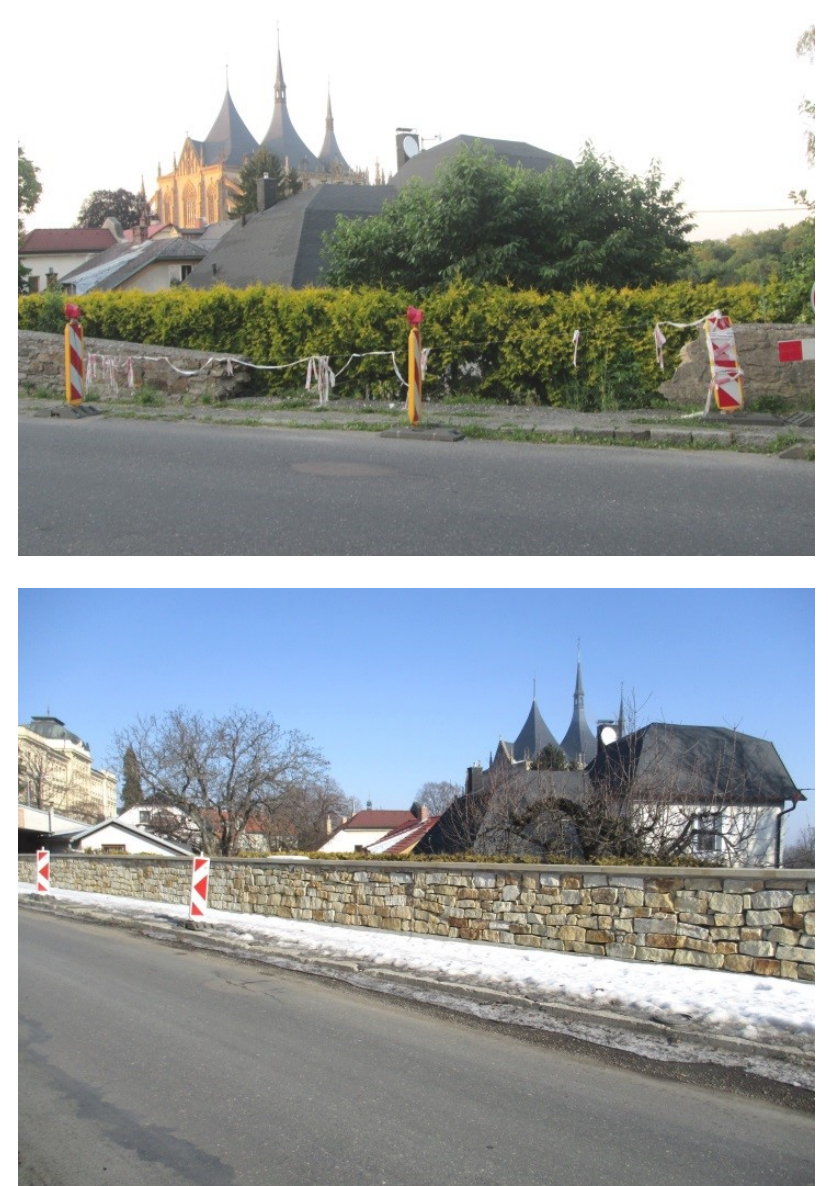

Figure 2. View of the original (top) and new wall (bottom) near St. Barbara's dome.

\section{Georadar - A Geophysical SuRVEY METHOD}

With respect to the above mentioned facts the question of other disrupted places was raised during the construction process. These faults could in the future endanger not only the new retaining wall but also the adjacent carriageway that has itself been reconstructed during the construction including the new structural pavement layers.

Gravimetric data were processed and evaluated. The principal result of the survey led to the finding that there was several other places under the road where there existed relatively continuous ranges with a lack of material. From the geophysical point of view it was recommended to rehabilitate these places preferably with injections to the depth of $10 \mathrm{~m}$.

The use of georadar in the final stage of the construction process in order to check the roadbed proved to be positive and valid 3 . It was decided to replace the original pavement design (reduced pavement structure in one half of the carriageway and only reconstruction of asphalt layers in the other half) for a complete reconstruction of the road structure in the whole rebuilt section.

\section{Conclusions}

Design work started with the contract owner's request to appraise the static assessment for the original retaining wall by Libor Pokorný. Just after the first inspection of the wall and road in question the author of this appraisal pronounced the static situation to be very serious, and endangering not only traffic.

The issue gradually developed from a small problem of carriageway slump and collapse of a rather small part of the wall to the bigger problem of global wall instability including the presence of undermining under the road. The amount of work needed gradually increased. The situation had to be solved quickly and as a complex whole. The designer's thoroughness and often indeed intransigence paid off because a complex interconnected solution was carried right through to finality.

The active cooperation of all affected authorities and organizations, contract owners - KSUS and the municipality of Kutná Hora, with both contractors and the designer was a necessary condition for managing the situation. Property relations responsibilities complicated the problem solving, because the road owner is the Central Bohemian Region, while sidewalks and some of the walls belong to the town of Kutná Hora, and then leaving a major part of the walls belonging to private owners. For this reason a memorandum for a common course of action was initiated. Besides the Property Municipality Department and Traffic Municipality Department, the officers from Municipality Department for National Heritage, Education and Culture of Kutná Hora took part in the Monitoring Board. They consulted each other actively regarding the shape and appearance of the new wall and participated on the selection of proper stone, or possibly and more precisely the source quarry for the new wall lining. Respected experts from the Department of Geotechnics of the FCE of CTU Prague (Prof. Jiří Barták and Assoc. Prof. Jan Masopust) also made a considerable contribution.

Taking account of the danger of delay a very unusual instance of cooperation with the private owners of the surrounding estates was established, and this led to a prompt start to the process of implementing the geotechnical monitoring and then on to the construction work itself. The structure was deemed in the $3^{\text {rd }}$ geotechnical category because of its complexity, and this made GTM necessary.

Local citizens themselves understood the importance of the situation and enabled their objects for passport and surveying point installation and facilitated incident-free surveys. The initial meeting was held in the municipal hall with the attendance of the town officials, representatives of the offering party, contractor and designer. The designer gave a detailed presentation on the design construction activities.

An individual approach to the private owners in the affected zone proved to be crucial. Personal exchange and discussion on any particular problems 
proved much more advantageous than relying on written receipted and recorded correspondence. It brought benefits during the construction process, when hazardous works were performed near the objects and there was a need for safety monitoring and controlling the condition of objects.

Mutual reliance among all partners in the building process, involving the fulfilment of assurances and keeping to deadlines, proved to be an essential condition for successful construction management of such a complex structure.

\section{REFERENCES}

[1] P. Turček. Foundation Engineering (Zakládání staveb). Jaga, Bratislava, 2005.

[2] J. Bílek. Kutnohorské dolování. Kuttna, 2000.

[3] J.-L. Briaud. Geotechnical Engineering: Unsaturated and Saturated Soils. Wiley, New York, 2013.
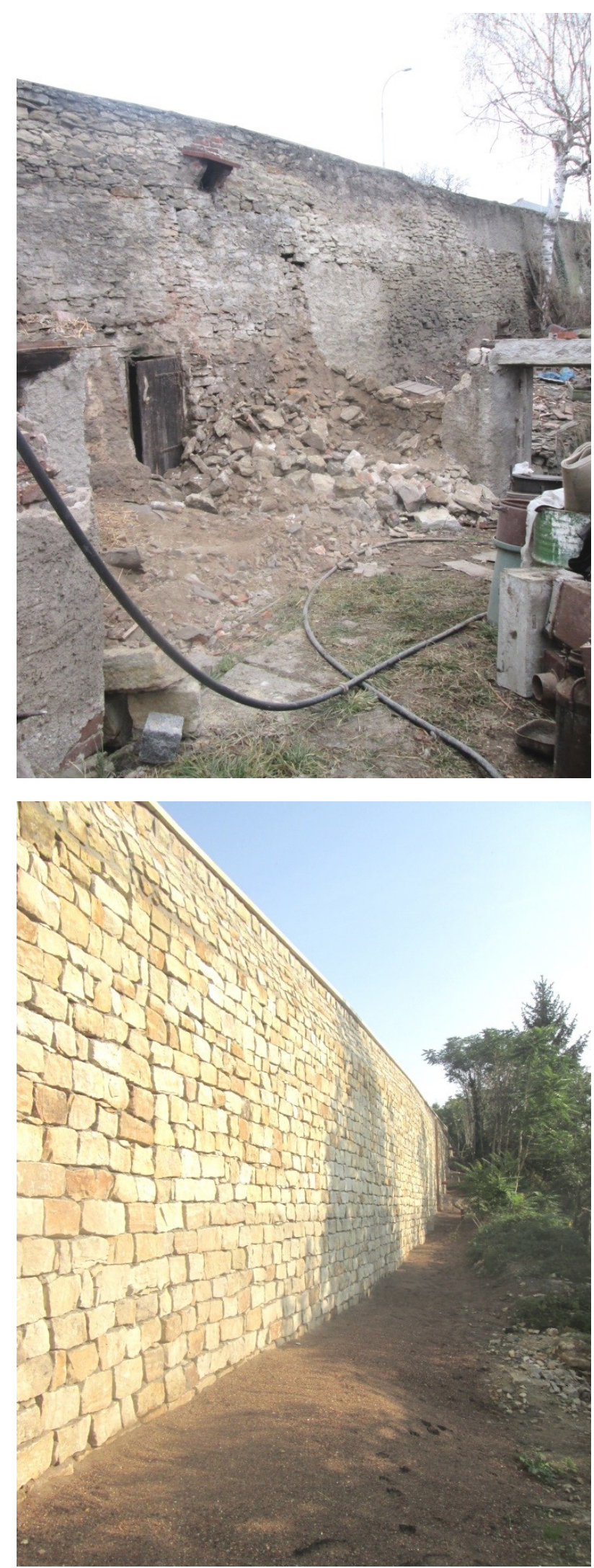

Figure 3. Structural condition comparison: the old (top) and the new wall (bottom). 